\title{
Legitimacy, stratification, and internationalization in global higher education: the case of the International Association of Universities
}

\author{
Mike Zapp ${ }^{1} \cdot$ Jens Jungblut ${ }^{2,3}$ (D) . Francisco O. Ramirez ${ }^{4}$ \\ Received: 8 April 2020 / Accepted: 5 October 2020 / Published online: 27 October 2020 \\ (C) The Author(s) 2020
}

\begin{abstract}
The International Association of Universities (IAU) is the only inclusive global university association, its membership barriers are low, yet few universities are members despite considerable benefits. What determines membership in this long-standing international university alliance? Reviewing recent trends toward a more networked, stratified and internationalized global higher education field, we argue that universities with a greater need for legitimation and those 'born' into a global era are more likely to become members of an inclusive international network like the IAU. Thus, we expect lower status and younger universities to be more likely to join. We apply regression models to test hypotheses implied by these arguments. Our findings are consistent with these hypotheses, even after controlling for other factors. We discuss these findings using neo-institutional arguments about legitimacy and imprinted logics and suggest potential analytical avenues for further research.
\end{abstract}

Keywords Meta-organization · University alliance · International Association of Universities · Legitimation $\cdot$ Imprinting $\cdot$ Internationalization

Electronic supplementary material The online version of this article (https://doi.org/10.1007/s11233-02009062-0) contains supplementary material, which is available to authorized users.

Jens Jungblut

jungblut@stv.uio.no

Mike Zapp

mike.zapp@uni.lu

Francisco O. Ramirez

ramirez@stanford.edu

1 Department of Social Sciences, University of Luxembourg, Esch-sur-Alzette, Luxembourg

2 Department of Political Science, University of Oslo, Oslo, Norway

3 SCANCOR / Graduate School of Education, Stanford University, Stanford, CA, USA

4 Graduate School of Education, Stanford University, Stanford, CA, USA 


\section{Introduction}

Over the past two decades, higher education has become a highly interconnected and nested global organizational field, in which the UNESCO-affiliated International Association of Universities (IAU) occupies a prominent position as one of the first and the only genuinely global and inclusive meta-organizations, i.e. organization that has other organizations as members (Berkowitz and Bor 2017). Despite its broad range of missions and membership benefits, membership in the IAU is strikingly low, with currently only $3.2 \%$, or $N=551$, of the global higher education field $(\sim 16,978)$ being a full (institutional) member of the IAU. This raises the question, what determines universities' decision to join such a meta-organization in global higher education?

To explain membership in the IAU, we are guided by two different but overlapping theoretical traditions in organizational analysis. From a neo-institutional perspective, organizations seek legitimacy, which often entails enacting an appropriate or 'proper' organizational identity (Drori et al. 2006; March 1982; Meyer and Rowan 1977; Suchman 1995). The need to display such proper identity is particularly evident in lower status and less affluent organizations. In the realm of higher education, looking like a "real" university is crucial, especially for organizations lacking reputation (Hüther and Krücken 2016; Stensaker et al. 2019). For these universities, joining the easy-to-enter and welcoming IAU is an attempt to enhance legitimacy as well as visibility and to access its resources. By contrast, higher-status universities are less likely to join the IAU. In an era of international rankings and a "world class" university discourse, what constitutes a "real" university becomes more standardized and who are perceived as the higher status universities becomes more evident (Buckner 2020; Frank and Meyer 2020).

Thinking about historical eras and their influence on universities leads us to the imprinting perspective. Stinchcombe (1965) argued that organizational structures and strategies were heavily influenced by the conditions in which organizations were born, that is, by the dominant and persistent institutional logics of the specific era in which they came into existence (Oertel 2018; Oertel and Söll 2017). Even though there are serious and ongoing debates as to what constitutes internationalization (Buckner 2017, 2019, 2020; Knight 2014; Kosmützky and Putty 2016), the post-World War II era clearly emphasizes internationalization in higher education as a desideratum more so than in earlier time periods (Ramirez 2006; Chou et al. 2017; Parreira do Amaral 2010; Powell et al. 2017; Seeber et al. 2016; Stensaker et al. 2019). In this perspective, one would expect younger universities to be more attracted to membership in the IAU as a way of displaying commitment to internationalization, and thus, to looking like a "proper" university. Older universities are more likely to rely on other and often more exclusive strategies of internationalization, from entering into alliances with peer institutions to marketing themselves for foreign students (Buckner 2020).

These perspectives overlap insofar as they both emphasize the importance of managing organizational identity in accounting for organizational decisions. From these perspectives, joining the IAU is organizational behavior influenced by legitimacy- seeking due to lower status and to being born in the era of internationalization as a dominant institutional logic in higher education.

In what follows, we first situate the International Association of Universities within global higher education governance. Next, we elaborate the core arguments and their empirical implications. Drawing on the IAU's World Higher Education Dataset, we apply logistic regression models to test these implications, controlling for a number of other variables that 
may also be influential. Our main findings are consistent with the core arguments. We discuss these findings and conclude by reflecting on the challenges an inclusive meta-organization like the IAU faces in the stratified and competitive global field of higher education.

\section{Global higher education governance and the International Association of Universities}

Higher education worldwide has seen important changes in recent decades concerning both universities themselves and their governance (Schofer and Meyer 2005). Universities have recently been re-conceptualized from 'specific organizations' of public administration (Musselin 2007) to 'autonomous', 'normal', 'complete', 'real', 'formalized' and even 'empowered' organizations (Brunsson and Sahlin-Andersson 2000; Krücken and Meier 2006; Musselin 2009). As part of this process, universities increasingly have to display their legitimacy while facing pressures to become more autonomous, accountable, excellent, relevant, and international (Ramirez 2010). At the level of national governance, policymakers' discourses have shifted from a focus on national development to one of global competitiveness (Buckner 2017).

This leads to a situation where universities are increasingly in competition with each other in a (global) race for reputation, revenues and researchers (Brankovic 2018b; Hazelkorn 2015; Musselin 2018; Vukasovic and Stensaker 2018). Situated in such a global competitive field, higher education has become the target of particular interest and policy directives. In particular, national and international ratings and rankings (e.g. the Times Higher Education World University Rankings) create new logics of quantification, comparison, distinction and stratification (Espeland and Sauder 2007, 2016; Espeland and Stevens 2008). Furthermore, universities increasingly face a new environment characterized by a sprawling governance architecture made of international and regional as well as governmental and nongovernmental actors organized in an international regime. For example, international higher education conferences, national and regional higher education qualification frameworks as well as regional recognition conventions have diffused dramatically in the past two decades (Zapp and Ramirez 2019; Zapp et al. 2018).

Operating within this global educational regime, universities become more sensitive to their place in the international status order. Universities are also more aware that internationalization is very much favored in this global educational regime (Buckner and Zapp 2020; Zapp and Lerch 2020; Buckner 2020). Thus, they have started to strategically position themselves globally through inter-university networks or associations ${ }^{1}$ and elaborate internationalization strategies (Brankovic 2018b; Seeber et al. 2016; Vukasovic and Stensaker 2018). The mobility of staff and students, programs and campuses, internationalized curricula, international research collaborations and partnerships have become routine features of the modern university (Knight 2014; Powell et al. 2017; Ramirez 2006). As a result, universities, across countries, band together to a degree unseen before. Brankovic (2018a), tracing the emergence of university associations over time, finds 185 associations with most of them being regional or global and burgeoning in the past two decades. Some of these associations are small and exclusive, while others are large and span entire continents.

\footnotetext{
${ }^{1}$ Even though some authors prefer one term over the other, for our study we do not distinguish between a university network or an association but treat the two terms interchangeably.
} 
To summarize, universities increasingly operate in a competitive global environment in which their place in an international status order is dramatized through regional and world rankings. Within this global environment, internationalization is clearly favored. As organizational actors, universities have to showcase their legitimacy and are expected to be proactive and make decisions to enhance their status. In this, membership in university alliances has become an important mechanism to display legitimacy and upgrade organizational standing (Gunn and Mintrom 2013; Brankovic 2018a). We now turn to the IAU as a prime example of such alliances.

\section{The International Association of Universities as a meta-organization in global higher education}

In the increasingly dense field of global higher education, the International Association of Universities (IAU) is unique in many regards. Founded in 1950, it is the second oldest global association concerned with universities, ${ }^{2}$ established prior to most regional and other international associations that took off in the late 1950s and 1960s.

The IAU, an offspring of UNESCO, has been created as a forum for universities to come together without representatives from national governments and it stands for a number of core democratic values, most prominently, academic freedom. With a truly global mission that reflects its affiliation with UNESCO, the IAU had long been the only association that accepts members from all geographic areas of the globe. Further, with its inclusive mandate, the IAU is unique compared to more recent associations whose membership is either confined by geography (e.g. the Network of Universities from the Capitals of Europe - UNICA), mission (Global University Network for Innovation) or "excellence" (e.g. the League of European Research Universities - LERU) (Brankovic 2018a; Gunn and Mintrom 2013). Finally, unlike many of the more recent specialized organizations, the IAU is also one of the few major organizations in the field of higher education that works across various policy areas. It has active involvement in discourses linked to internationalization, quality assurance, intercultural learning, the use of technology or sustainable development.

Barriers to IAU membership are relatively low. Institutional characteristics of potential members are almost all-encompassing; higher education institutions need to be recognized as a public or private higher education institution and need to have undergone accreditation or quality assurance. They are also required to confer a first terminal degree and need to have completed at least three cohorts of students (IAU 2020). Membership fees are low. Small universities from low-income countries start at $€ 950$ p.a. and a maximum of $€ 3250$ p.a. is charged for large universities located in high-income countries (IAU 2020). In addition, if a member is unable to pay its membership fee, it can stay listed as a member of IAU for up to three years before its membership will end due to outstanding fees.

By contrast, there are several benefits of membership. Members take an active part in IAU's governance through voting and elections. They can access IAU's international networks, conferences, data, libraries and other media. They can take part in workshops and other professional development formats such as leadership trainings and use them to liaise with other universities. They benefit from trends analyses, specialized portals, advisory services, training and peer-to-peer learning as well as global advocacy and representation (IAU 2020).

${ }^{2}$ Only the Association of Commonwealth Universities is older. 
Moreover, the IAU explicitly highlights that members gain visibility through their affiliation, presumably increasing the status of their members.

As an inclusive, open, global and non-expensive organization with considerable benefits, we see the IAU as an almost ideal-typical meta-organization, i.e. an organization that has other organizations as members (Ahrne and Brunsson 2005, 2008). Meta-organizations have become an important concept in organization studies where it helps understand organizational field construction and composition as well as organizational behavior and inter-organizational relations (Ahrne and Brunsson 2005, 2008; Berkowitz and Bor 2017). These are emerging questions also in higher education where university behavior is undergoing strategic changes and inter-university relations are being globally reshuffled, especially when considering the growing number of higher education meta-organizations in the form of inter-university associations (Brankovic 2018a).

Considering IAU's characteristics and status as the only genuinely global higher education meta-organization, it should, in principle, attract members from all countries and all strata of higher education systems alike. However, only a small percentage, $3.2 \%$ or $N=551$, of the global higher education field $(N=16,978)$ has joined the IAU as full (institutional) members. It seems that membership in university associations, even in situations of low entrance barriers, involves a more complex process. In what follows we set forth our core arguments about IAU membership determinants and present the data with which we test the related hypotheses.

\section{Explaining membership in the International Association of Universities}

Following our interest to investigate why some universities are more likely to become members of the IAU, we contend that universities in greater need for legitimacy are especially driven towards membership. This view is based on the two previously outlined arguments from neo-institutional theory and the imprinting perspective in organizational research. Following these approaches, we develop two matching hypotheses that are the basis for our subsequent analysis.

Our first argument emphasizes the importance of legitimacy for organizations. This core idea in organizational theory sees meta-organizations as an important means for members to gain legitimacy. It also resonates with neo-institutional theories where organizational structures and policies are legitimation-seeking exercises, not simply technical rational ones (Meyer and Rowan 1977; Bromley and Powell 2012). In this approach, organizations are embedded in a cultural environment that provides models, which indicate appropriate behavior and thus supply legitimacy. As organizations seek legitimacy, they undertake activities in line with these models to act in accordance with generally-accepted rules and norms. In this, legitimacy is the support that the environment provides to an organization based on the appropriateness of its actions (Suchman 1995). In the context of global higher education, top universities enjoy abundant legitimacy; they are even the templates for organizational reform around the globe (Buckner 2020). Those not in the top of global rankings, however, are more likely in need for a strong external basis for their legitimacy. In addition, being on top of international rankings also tends to go hand in hand with more organizational capacity and resources. This means that those universities that are ranked in the top of rankings should be less in need of the services and resources provided by the IAU, especially the increased visibility and the opportunity for networking. Thus, membership in the IAU should be more attractive to those universities that do not do well in international rankings. 
H1: Universities that are ranked in the top of international rankings are less likely to join the IAU.

In a related vein, young universities that have been created in a time when the internationalization trend was especially strong can be expected to be more strongly inclined to join the IAU. As these younger organizations have to catch up to the older and more established universities that shape the dominant models in the global higher education field, they use the globalized narrative of excellent and international universities to signal their legitimacy (Buckner and Zapp 2020; Buckner 2020; Oertel and Söll 2017; Stensaker et al. 2019). This resonates with the concept of imprinted institutional logics, an idea that has proven useful in explaining similarities in organizational structure and behavior within and across fields and periods (Thornton et al. 2012). Combining the imprinting concept with institutional logics, we emphasize the crucial role of inceptive phases together with the importance of ideational and cognitive forces that motivate organizational behavior (Waeger and Weber 2019). In this perspective, logics have strong legacies. For example, analyzing corporate social responsibility activities in a large sample of Chinese companies, Raynard et al. (2013) find that cognitive frames reflect a state logic that was more dominant in an earlier era, and argue that the earlier frame, once imprinted, remained salient. Similarly, the time of university creation has an influence on the way it adapts to an existing environment and signals its status and belonging (Zapp and Lerch 2020; Oertel 2018; Oertel and Söll 2017). In this sense, younger universities are more likely to look to international organizations such as the IAU to seek legitimacy and use the IAU's prominent and unique status in global higher education governance and its link to UNESCO to augment their standing and underline their participation in the global organizational field of higher education.

\section{H2: Younger universities are more likely to be IAU members.}

\section{Data and methodology}

We draw on the World Higher Education Database (WHED), which has been created and updated by the IAU in collaboration with UNESCO since the 1950s. The WHED is the most comprehensive and authoritative dataset on universities worldwide. The data provided is for the most-recent year and thus only cross-sectional. The data for our study refers to the years 2016-2017. The original dataset comprises information on $N=16,978$ colleges and universities from 191 countries and independent territories. The information is provided to the IAU by official public sources and complemented by IAU staff through direct contact with higher education institutions. Information comprises, among others, full original and English titles, founding dates, type of funding and legal status (private vs public), student enrollment and formal organizational structure as well as curricula. All higher education institutions included offer at least a 3-4 years first terminal degree (ISCED 6A/B).

This rich dataset does, however, have some limitations. ${ }^{3}$ First, public institutions may be overrepresented as they more readily enter public records than private higher education institutions. Second, the IAU updates the data every year but uses a specific regional focus each year for the update. The 2018 update, for example, focused on Asia and the Middle East.

\footnotetext{
${ }^{3}$ See also: http://whed.net/home.php (06.04.2020)
} 
Consequently, there might be a difference of up to 5 years between regions with regard to the timeliness of the information. Finally, the database relies on data reported by public authorities and higher education institutions themselves. As the IAU is not responsible for data collection, some data might include elements of organizational window-dressing. However, even with these limitations the data from the WHED still represents the most comprehensive and reliable dataset on higher education institutions in the world.

\section{Analysis and variables}

Outcome variable Our dependent variable is institutional membership in the IAU. We only use institutional membership $(N=551)$ for 2016, and discard all affiliated, associated or organizational members $(N=111) .{ }^{4}$ There are three reasons for this sampling strategy. First, higher education institutions make up the largest part of the membership body. Second, all other types of members may also include other meta-organizations (e.g. university associations) or individuals. Third, the IAU was originally created to provide a meta-organization in which universities could organize without the involvement of national governments. Historically, higher education institutions are the main audience of the IAU. Consulting with the IAU, we have been reassured that each member re-assesses its membership on a regular basis and that there are no dormant memberships (a situation that would hamper the robustness of our analysis).

Key predictors We use the results of the Times Higher Education (THE) World University Ranking (WUR) from 2018 to indicate university status. We draw on the THE WUR as it is one of the most comprehensive rankings, yet does not methodologically overlap with our own predictors (THE WUR 2020). We select the top 500 universities in the world as our cut-off point. Age is defined by years of existence based on the universities' founding date through 2017 (WHED 2020). We use a z-transformed variable for age. Alternatively, we run a model with a binary age/ cohort variable using 1990 as a cutting value (see Appendix table A2), yet results show almost no difference.

Control variables We control for a number of other organizational and country-level variables. Regional coding assesses the university's location and is based on the UN classification of world regions. Given IAU's founding context, we use Europe as a reference category.

The distinction of university type, i.e. private (not-for-profit) versus public, is based on IAU's classification of universities' legal status. We use public universities as a reference as private universities were less prominent at IAU's onset.

We also use a logged student enrollment measure to test for the effect of universities' size. In doing so, we excluded some outliers.

We draw on a widely used index to compare political systems, the Polity IV Index, to measure whether the level of democracy of a country in which a university is situated has an impact on its likelihood to join the IAU. Polity IV ranges from -10 (highly autocratic) to +10

\footnotetext{
${ }^{4}$ IAU has four categories of members: 1) institutions, which is by far the largest category and the one that we are interested in. This category comprises those universities that are full IAU members, 2) organizations such as other national, regional or global higher education associations, 3) affiliates such as non-governmental organizations or networks in education, and 4) associates such as individuals collaborating with the IAU on a project-basis. See also: https://www.iau-aiu.net/Members (06.04.2020)
} 
(highly democratic) (Center for Systemic Peace 2018). We use a high level of democracy as a reference based on IAU's core values.

Lastly, we control for the level of internationalization of a university measured through three indicators of university organizational structure that cater to the task of internationalization. First, through a binary variable we ascertain whether a university has an international office as indicated in the WHED (WHED 2020). Second, we code the prevalence of a variety of international studies in the curriculum based on WHED (2020) data on degree designations (e.g. international relations, area studies, international business administration). Our variable captures the existence of at least one explicitly international study program as a binary variable. We also built models with a metric variable describing the total number of international study programs as a share of the total teaching portfolio yet results show no difference (see Buckner and Zapp 2020; Zapp and Lerch 2020 for details). Third, we include a control for membership in regional university associations (see Buckner and Zapp 2020; Zapp and Lerch 2020 for details). Based on membership directories, we coded a binary variable indicating whether a university is a member in a regional association (e.g. the European University Association).

Model Logistic regression is appropriate for modeling the likelihood of membership prevalence and estimating the magnitudes of effects for various predictors. However, basic logistic regression models are unable to adequately account for data that result from cluster sampling within universities and countries. The WHED includes such data. We use multilevel modeling to achieve a more accurate estimation of university-level effects within separate countries (i.e., within-country effects), as well as accurate estimations of the unique influences of the university environment.

We run multi-level binary logistic regressions with fixed effects in order to handle the nested data (i.e. membership of universities located in countries) (Wong and Mason 1985). We chose fixed effects due to the large sample size and an explicit interest in the covariates. The full estimated model takes the following equation:

$$
Y_{i j}=\beta_{0}+\beta_{1} A_{i j}+\beta_{2} B_{i j}+\beta_{3} I O_{i j}+\beta_{4} M_{i j}+\beta_{5} I S_{i j}+\beta_{6} Z_{i j}+\varepsilon_{i j}+\beta_{7} W_{j}+\mu_{j}
$$

where $Y_{i j}$ is the measure of membership for university $i$ in country $j . A_{i j}$ describes the age for an institution $i$ in country $j$ and $B_{i j}$ its status rank. $I O_{i j}$ describes whether an institution $i$ in country $j$ has an international office, $M_{i j}$ whether an institution $i$ in country $j$ is member of a regional university association and $I S_{i j}$ whether an institution $i$ in country $j$ has an internationalized curriculum. $Z_{i j}$ represents controls at the organizational level and $\varepsilon_{i j}$ the residuals at the organizational level. $W_{j}$ represents control variables at the country level and $\mu_{j}$ the residuals at the macro-level.

Table 1 below provides descriptive statistics for all variables. Table A 1 in the appendix provides a correlation matrix for all independent variables with no problematic associations observed. As we have a very large sample, Appendix A also shows a boot-strapped model to warrant accuracy of our interpretations. We also recognize the limitations that our crosssectional design has, as it does not allow us to ascertain the direction of some associations. For example, IAU membership may drive some organizational efforts to internationalize or, reversely, these organizational characteristics have an influence on the likelihood to become a member of the IAU. Therefore, we caution against strong causal interpretations. 
Table 1 Sample description

$\mathrm{N} \quad \mathrm{Me} \quad \operatorname{std} \quad \min \quad \max$

\begin{tabular}{|c|c|c|c|c|c|}
\hline \multicolumn{4}{|l|}{ Key Predictors } & 0 & 1 \\
\hline age & 16,576 & 58 & 67 & 2 & 1284 \\
\hline \multicolumn{6}{|l|}{ World Regions } \\
\hline Asia & 16,978 & 0.27 & 0.44 & 0 & 1 \\
\hline CEE \& Central Asia & 16,978 & 0.10 & 0.30 & 0 & 1 \\
\hline Western Europe & 16,978 & 0.11 & 0.31 & 0 & 1 \\
\hline Latin America & 16,978 & 0.22 & 0.42 & 0 & 1 \\
\hline MENA & 16,978 & 0.05 & 0.22 & 0 & 1 \\
\hline North America & 16,978 & 0.14 & 0.35 & 0 & 1 \\
\hline Sub-Saharan Africa & 16,978 & 0.06 & 0.24 & 0 & 1 \\
\hline \multicolumn{6}{|l|}{ Organizational controls } \\
\hline type & 16,978 & & & 0 & 1 \\
\hline area & 16,978 & & & 0 & 7 \\
\hline size & 12,715 & 10,758 & 31,672 & 7 & $1.4 \mathrm{M}$ \\
\hline \multicolumn{6}{|l|}{ Internationalization controls } \\
\hline regional membership & 16,978 & & & 0 & 1 \\
\hline international office & 16,978 & & & 0 & 1 \\
\hline international curriculum & 16,978 & & & 0 & 1 \\
\hline \multicolumn{6}{|l|}{ Country-level controls } \\
\hline Polity IV & 16,978 & .86 & .35 & -10 & 10 \\
\hline
\end{tabular}

Codes refer to: type: 0 = private; 1 = public; area, regional membership, international office, curriculum, excellence: $0=$ No; $1=$ Yes; Polity IV: $-10=$ most undemocratic; $10=$ most democratic

\section{Results}

Table 2 provides a synopsis of IAU members by region. ${ }^{5}$ The percentage of membership for each region relates to the proportion of universities from that region which are IAU members. Interestingly, membership is comparatively high in Africa, the Middle East and Northern Africa, Western and Eastern and Central Europe as well as Oceania, while North American and Latin American universities are least represented in the IAU.

What Table 2 indicates is that membership in the IAU is not driven by those regions with universities that command the most attention in global rankings and in discourses about worldclass universities. This descriptive finding suggests that joining the IAU may be due to factors other than the centrality of a national higher education system within a global environment.

We present our statistical model to examine the hypotheses advanced earlier. The model tests the legitimacy hypotheses with our controls including those focusing on university internationalization (Table 3).

Our model shows that both of the main hypotheses are confirmed. Being ranked among the THE Top 500 universities significantly lowers the likelihood for IAU membership with a moderate effect size $\left(\mathrm{B}=-.69^{* * *}\right)$. The effect for age is smaller, yet also significant, and it follows the expected direction $(\mathrm{B}=-.12 * *)$ : The younger a university, the more likely it will join the IAU.

\footnotetext{
${ }^{5}$ Since our dataset represents a quasi-census of the global higher education organizational population, we do not run any t-test to control for significant differences.
} 
Table 2 IAU membership by area

\begin{tabular}{|c|c|c|c|c|c|c|c|c|c|c|}
\hline & & Africa & Asia & $\begin{array}{l}\text { Eastern } \\
\text { and } \\
\text { Central } \\
\text { Europe }\end{array}$ & $\begin{array}{l}\text { Middle } \\
\text { East and } \\
\text { Northern } \\
\text { Africa }\end{array}$ & $\begin{array}{l}\text { North } \\
\text { America }\end{array}$ & $\begin{array}{l}\text { Latin } \\
\text { America } \\
\text { and } \\
\text { Caribbean }\end{array}$ & Oceania & $\begin{array}{l}\text { Western } \\
\text { Europe }\end{array}$ & Total \\
\hline \multirow[t]{3}{*}{ members } & count & 61 & 122 & 83 & 102 & 33 & 40 & 15 & 95 & 551 \\
\hline & $\begin{array}{l}\text { \% within } \\
\text { IAU } \\
\text { member- } \\
\text { ship }\end{array}$ & 11.1 & 22.1 & 15.1 & 18.5 & 6.0 & 7.3 & 2.7 & 17.2 & 100.0 \\
\hline & $\begin{array}{c}\% \text { within } \\
\text { area }\end{array}$ & 6.3 & 2.2 & 4.0 & 9.7 & 1.6 & 1.1 & 12.0 & 5.8 & 3.2 \\
\hline
\end{tabular}

Table 3 Estimates for IAU membership determinants

Estimates

Key Predictors

top 500

$-.69 * * *$

(.19)

age

$-.12 * *$

(.05)

Area Controls

Area (Reference: Western Europe)

Africa

Asia

Eastern \& Central Europe

$-1.29 *$

Middle East \& Northern Africa

(.56)

$-2.66 * * *$

(.73)

North America

Latin America \& Caribbean

Oceania

Organizational controls

public university

size

democratic country

Internationalization controls

international office

international curriculum

regional member

Standard error in parentheses; $N=12,715$;

$* p<.05 ; * * p<.01 ; * * * p<.001$ 
The results show that the status and age of the university continue to show the expected effects, even when controlling for international office, internationalized curriculum and regional association membership. That is, lower status and younger universities were more likely to join, irrespective of the influence of organizational efforts by the university to internationalize.

Controls yield some interesting findings. University size and whether the university is located in a more democratic polity are inconsequential, at least treated as isolated variables. This is a somewhat surprising finding, since the IAU promotes core democratic values that should have made it less attractive to universities in more autocratic polities. However, it may well be that some universities in autocratic polities join because their aspirations are more democratic than those of their political regime. ${ }^{6}$ In addition, we find that public universities are more likely candidates for IAU membership. Lastly, relative to Western Europe, being situated in Oceania, Eastern \& Central Europe, Africa and the Middle East \& Northern Africa shows significant negative effects on the likelihood of membership. This is somewhat surprising compared to the previously presented descriptive statistics on the spatial distribution of IAU membership.

\section{Discussion}

Despite the general trend towards more internationalization, its low-entry costs and sizable benefits, the IAU attracts only a few universities as members today. At the same time, the IAU is one of the oldest university associations in the world and it has a solid core of universities as members. This paper offers explanations as to why these join and others not. We rely on ideas from neo-institutional and organizational imprinting theories. We used arguments from sociological neo-institutionalism to focus on the wider environment and see organizational developments as attuned to the changes in the rules or standards of the organizational field focusing specifically on legitimacy. We also used arguments from organizational imprinting to call attention to the influence of the dominant institutional logic at the founding of the organization.

What our findings suggest is that the influence of the wider field is greater on those universities with an increased need for legitimacy and external validation of their university identity. The impact is also higher on those for which the logic of internationalization is most compelling as a means of identity validation.

Let us briefly reflect on each of these core findings. First, the need for external legitimacy has been a key determinant for the likelihood of joining the IAU. In this regard, high status universities may be more immune, and even if inclined, may prefer not to join a globally inclusive meta-organization. In the stratified global field of higher education, the more prestigious universities may prefer to stick to each other in more exclusive networks such as small alliances that only admit very selected and "excellent" members (Gunn and Mintrom 2013; Brankovic 2018a). Birds of the same feathers may indeed flock together, especially if the feathers are already esteemed. This may explain why we find that the less prestigious universities are more likely to become members. The top 500 of the THE WUR do not need the IAU to validate their legitimate identity as a university. Their legitimacy is derived from their globally validated excellence via their standing in world rankings and from the generally more positive perception enjoyed by the more established universities (Christensen et al.

\footnotetext{
${ }^{6}$ We would like to thank one of the anonymous reviewers for pointing this out to us.
} 
2018). Joining an inclusive and heterogeneous association such as the IAU is not seen as gaining them more status and distinction as suggested by the meta-organization literature (Ahrne and Brunsson 2008). Instead, these organizations create their own associations such as the League of European Research Universities (LERU) signaling exclusiveness and boundarydrawing (Brankovic 2018a).Our analysis of IAU membership reveals the ongoing process of higher education stratification at a global scale by adding "associational structure" to a process that has thus far mainly been analyzed in terms of global rankings (Hazelkorn 2015).

While having a recognized status makes IAU membership less likely, young age is positively associated with membership in the IAU. This might be explained by the fact that younger universities are less likely to have these reputational advantages and more likely to display internationalization commitments via membership in an inclusive meta-organization. They see such membership as legitimacy-enhancing and as a potential source of resources to grow their reputation.

At the same time, we point to another potential reason for why younger universities join the IAU. We argue that universities 'born' into an internationalized era are confronted with a different institutional logic made of era-specific cognitive frames (Raynard et al. 2013; Thornton et al. 2012). In this perspective, universities reflect the dominant logic that prevails during their formative phase. In the case of universities, internationalization can certainly be considered a powerful narrative that steadily increased its relevance in the last decades (Buckner and Zapp 2020; Zapp and Lerch 2020; Buckner 2017, 2020). We extend the research on the environmental penetration of universities that has so far shown effects on universities' diversity strategies as well as study programs and structure (Oertel 2018; Buckner and Zapp 2020; Zapp and Lerch 2020) by directing attention to universities' internationalization decisions that can partly be explained by contemporary expectations of what constitutes a 'proper' university. The additional finding that IAU membership is associated with international offices and curricula as well as regional memberships indicates an emerging 'internationalist' type of university. While the literature highlights that internationalization has multiple meanings for different universities and is articulated in different ways (Buckner and Zapp 2020; Zapp and Lerch 2020; Ramirez 2006; Buckner 2020; Seeber et al. 2016; Stensaker et al. 2019), the correlation between these variables indicates that there is a cluster of institutions that increasingly embrace the aim to connect across boundaries.

\section{Conclusion}

This paper empirically identified the determinants of meta-organizational membership in the IAU, the only global and inclusive meta-organization in higher education. By focusing on organizational legitimacy and imprinted legacies of institutional logics, we unpacked what type of universities are more likely to join the IAU. Our aim with this study was to better understand the increasing global associational structure and stratification in higher education.

Our findings indicate that in a fragmented and stratified global organizational field, of which higher education is a prime example, characterized by increasing internationalization but also growing organizational competition, those universities that are in need of external legitimation are more likely to join the IAU. We explained the relevance of these factors by relating them to theories of organizational legitimacy and imprinted logics. The former looks to the wider environment and sees organizational developments as attuned to the changes in the rules or standards of the organizational field, particularly the search for legitimacy. The 
latter is used to make sense of why organizations seem to be influenced by the dominant institutional logic at the time of their foundation.

Our analysis highlights the challenges that the IAU but also other more inclusive metaorganizations face in an increasingly globally stratified organizational field like higher education. They have to maintain their own legitimacy and increase their constituency through inclusiveness and openness, while remaining attractive to those organizations that embrace global competition and are among the strongest and most prestigious players in the field. This is a delicate balance to strike especially in the context of an increasing number of more exclusive international university networks. Given the limitation of our study, the phenomenon of meta-organizations in higher education clearly demands future research. This includes, for example, longitudinal studies of membership dynamics in different types of alliances that go beyond the cross-sectional assessment that we could provide. Moreover, it is worth investigating the question how membership dynamics influence the activities, policies, and organizational processes of the networks themselves. Overall, a growing focus on university alliances using a meta-organizational perspective can contribute to a better understanding of both key dynamics in the organizational field of higher education especially regarding processes of internationalization and stratification in global higher education.

Acknowledgements The authors would like to thank the secretariat of the IAU for feedback on earlier versions of the paper. Moreover, the authors want to thank the participants of the SCANCOR seminar, Patricia Bromley, Niklas Harder, Marcelo Marques, and John Meyer for their helpful comments on earlier versions of the manuscript. Jens Jungblut acknowledges the financial support of the Research Council of Norway through its DIV-INT funding under project number 263544/F10.

Funding Open Access funding provided by University of Oslo (incl Oslo University Hospital).

Open Access This article is licensed under a Creative Commons Attribution 4.0 International License, which permits use, sharing, adaptation, distribution and reproduction in any medium or format, as long as you give appropriate credit to the original author(s) and the source, provide a link to the Creative Commons licence, and indicate if changes were made. The images or other third party material in this article are included in the article's Creative Commons licence, unless indicated otherwise in a credit line to the material. If material is not included in the article's Creative Commons licence and your intended use is not permitted by statutory regulation or exceeds the permitted use, you will need to obtain permission directly from the copyright holder. To view a copy of this licence, visit http://creativecommons.org/licenses/by/4.0/.

\section{References}

Ahrne, G., \& Brunsson, N. (2005). Organizations and meta-organizations. Scandinavian Journal of Management, 21(4), 429-449.

Ahrne, G., \& Brunsson, N. (2008). Meta-Organizations. Cheltenham: Edward Elgar.

Berkowitz, H., \& Bor, S. (2017). Why meta-organizations matter: A response to Lawton Et Al. and Spillman. Journal of Management Inquiry, 27(2), 204-211.

Brankovic, J. (2018a). How do meta-organizations affect extra-organizational boundaries? The case of university associations. In L. Ringel, P. Hiller, \& C. Zietsma (Eds.), Towards permeable boundaries of organizations? (research in the sociology of organizations) (pp. 259-281). Bingley: Emerald Publishing Limited.

Brankovic, J. (2018b). The status games they play: Unpacking the dynamics of Organisational status competition in higher education. Higher Education, 75(4), 695-709.

Bromley, P., \& Powell, W. W. (2012). From smoke and mirrors to walking the talk: Decoupling in the contemporary world. The Academy of Management Annals, 6(1), 483-530. 
Brunsson, N., \& Sahlin-Andersson, K. (2000). Constructing organizations: The example of public sector reform. Organization Studies, 21(4), 721-746.

Buckner, E. S. (2017). The changing discourse on higher education and the nation-state, 1960-2010. Higher Education, 74(3), 473-489.

Buckner, E. (2019). The internationalization of higher education: National Interpretations of a global model. Comparative Education Review, 63(3), 315-336.

Buckner, E. (2020). Embracing the global: The role of ranking, research mandate, and sector in the internationalisation of higher education. Compare: A Journal of Comparative and International Education online first, $1-18$.

Buckner, L. \& Zapp, M. (2020) Institutional Logics in the Global Higher Education Landscape: Differences in Organizational Characteristics by Sector and Founding Era. Minerva 1-25.

Center for Systemic Peace (2018) INSCR Data Page. . (http://www.systemicpeace.org/inscrdata.html).

Chou, M.-H., Jungblut, J., Ravinet, P., \& Vukasovic, M. (2017). Higher education governance and policy: An introduction to multi-issue, multi-level and multi-actor dynamics. Policy and Society, 36(1), 1-15.

Christensen, T., Gornitzka, Å., \& Ramirez, F. O. (2018). Universities as agencies: Reputation and professionalization. Basingstoke: Palgrave Macmillan.

Colyvas, J. A., \& Powell, W. W. (2006). Roads to institutionalization: The remaking of boundaries between public and private science. Research in Organizational Behavior, 27, 305-353.

Drori, G. S., Meyer, J. W., \& Hwang, H. (2006). Globalization and organization. Oxford: Oxford University Press.

Espeland, W. N., \& Sauder, M. (2007). Rankings and reactivity: How public measures recreate social worlds. American Journal of Sociology, 113(1), 1-40.

Espeland, W. N., \& Sauder, M. (2016). Engines of Anxiety: Academic rankings, reputation, and accountability. New York: Russell Sage Foundation.

Espeland, W. N., \& Stevens, M. L. (2008). A sociology of quantification. European Journal of Sociology, 49(03), 401-436.

Frank, D. J., \& Meyer, J. W. (2020). The University and the global knowledge society. Princeton University Press: Princeton.

Gunn, A., \& Mintrom, M. (2013). Global University alliances and the creation of collaborative advantage. Journal of Higher Education Policy and Management, 35(2), 179-192.

Hazelkorn, E. (2015). Rankings and the reshaping of higher education: The Battle for world-class excellence. Basingstoke: Palgrave Macmillan.

Hüther, O., \& Krücken, G. (2016). Nested organizational fields: Isomorphism and differentiation among European universities. In E. P. Berman \& C. Paradeise (Eds.), The University under pressure (pp. 53-58). Bingley: Emerald Group Publishing Limited.

IAU 2020. Membership. . (https://www.iau-aiu.net/Membership).

Knight, J. (2014). Three generations of crossborder higher education: new developments, issues and challenges. In B. T. Streitwieser (Ed.), Internationalisation of higher education and global mobility (pp. 43-58). Didcot: Symposium Books.

Kosmützky, A., \& Putty, R. (2016). Transcending Borders and traversing boundaries: A systematic review of the literature on transnational, offshore, cross-border, and borderless higher education. Journal of Studies in International Education, 20(1), 8-33.

Krücken, G., \& Meier, F. (2006). Turning the university into an organizational actor. In G. S. Drori, J. W. Meyer, \& H. Hwang (Eds.), Globalization and organization: World society and organizational change (pp. 241257). Oxford: Oxford University Press.

March, J. G. (1982). Theories of choice and making decisions. Society, 20(1), 29-39.

Meyer, J. W., \& Rowan, B. (1977). Institutionalized organizations: Formal structure as myth and ceremony. American Journal of Sociology, 83(2), 340-363.

Musselin, C. (2007). Are universities specific Organisations? In G. Krücken, A. Kosmützky, \& M. Torka (Eds.), Towards a multiversity? (pp. 63-84). Bielefeld: Transcript.

Musselin, C. (2009). New management responsibilities: The organizational transformation of European universities. In J. A. Douglass, C. J. King, \& I. Feller (Eds.), Globalization's muse: Universities and higher education Systems in a Changing World (pp. 371-384). Berkeley: Public Policy Press.

Musselin, C. (2018). New forms of competition in higher education. Socio-Economic Review, 16(3), 657-683.

Oertel, S. (2018). The role of imprinting on the adoption of diversity management in German universities. Public Administration, 96(1), 104-118.

Oertel, S., \& Söll, M. (2017). Universities between traditional forces and modern demands: The role of imprinting on the missions of German universities. Higher Education, 73(1), 1-18. 
Parreira do Amaral, M. (2010). Regime theory and educational governance: The emergence of an international education regime. In S. K. Amos (Ed.), International educational governance (pp. 57-78). Bingley: Emerald Group Publishing Limited.

Powell, J. J. W., Baker, D. P., \& Fernandez, F. (2017). The century of science: The global triumph of the Research University. Bingley: Emerald Group Publishing Limited.

Ramirez, F. O. (2006) The rationalization of universities. In: M.-L. Djelic \& K. Sahlin-Andersson (eds.) Transnational governance: Institutional dynamics of regulation, (pp. 225-244) Cambridge: Cambridge University Press.

Ramirez, F. O. (2010) Accounting for Excellence: Transforming Universities into Organizational Actors. In: L.M. Portnoi, V.D. Rust \& S.S. Bagley (eds.) Higher Education, Policy, and the Global Competition Phenomenon, (pp. 43-58) Basingstoke: Palgrave Macmillan.

Raynard, M., Lounsbury, M., \& Greenwood, R. (2013). Legacies of logics: Sources of community variation in CSR implementation in China. In M. Lounsbury \& E. Boxenbaum (Eds.), Research in the sociology of organizations: Institutional logics in action (pp. 243-276). Bingley: Emerald Group Publishing Limited.

Schofer, E., \& Meyer, J. W. (2005). The worldwide expansion of higher education in the twentieth century. American Sociological Review, 70(6), 898-920.

Seeber, M., Cattaneo, M., Huisman, J., \& Paleari, S. (2016). Why do higher education institutions internationalize? An investigation of the multilevel determinants of internationalization rationales. Higher Education, $72(5), 685-702$.

Stensaker, B., Lee, J. J., Rhoades, G., Ghosh, S., Castiello-Gutiérrez, S., Vance, H., Çalıkoğlu, A., Kramer, V., Liu, S., Marei, M. S., O’Toole, L., Pavlyutkin, I., \& Peel, C. (2019). Stratified University strategies: The shaping of institutional legitimacy in a global perspective. The Journal of Higher Education, 90(4), 539562 .

Stinchcombe, A. L. (1965). Social structure and organizations. In J. G. March (Ed.), Handbook of organizations (pp. 142-193). Chicago: Rand McNally \& Company.

Suchman, M. C. (1995). Managing legitimacy: Strategic and institutional approaches. The Academy of Management Review, 20(3), 571-610.

Thornton, P. H., Ocasio, W., \& Lounsbury, M. (2012). The institutional logics perspective: A new approach to culture, structure, and process. Oxford: Oxford University Press.

Vukasovic, M., \& Stensaker, B. (2018). University alliances in the Europe of knowledge: Positions, agendas and practices in policy processes. European Educational Research Journal, 17(3), 349-364.

Waeger, D., \& Weber, K. (2019). Institutional complexity and organizational change: An open polity perspective. Academy of Management Review, 44(2), 336-359.

Wong, G. Y., \& Mason, W. M. (1985). The hierarchical logistic regression model for multilevel analysis. Journal of the American Statistical Association, 80(391), 513-524.

World Higher Education Database [WHED] (2020) Home. Retrieved April 6, 2020. (http://whed.net/home.php).

World University Rankings [THE WUR] (2020) Times Higher Education. . (https://www.timeshighereducation. com/world-university-rankings).

Zapp, M. \& Ramirez, F. O. (2019) Beyond Isomorphism and Internationalisation. Towards a Global Higher Education Regime. Comparative Education, 55(4), 473-493.

Zapp, M. \& Lerch, J. (2020) Imagining the World. Conceptions and Determinants of Internationalization in Higher Education Curricula World wide. Sociology of Education, 93(4), 372-392.

Zapp, M., Marques, M. \& Powell, J. J. W. (2018) European Educational Research (Re)Constructed: Institutional Change in Germany, the United Kingdom, Norway, and the European Union. Oxford Studies in Comparative Education. Oxford: Symposium Books.

Publisher's Note Springer Nature remains neutral with regard to jurisdictional claims in published maps and institutional affiliations. 